\title{
THE PROGRAM FOR RURAL DEVELOPMENT FOR THE PERIOD 2014-2020 AS A FACTOR FOR THE RURAL REGIONS DEVELOPMENT
}

\author{
A. Miteva*, H. Petrov \\ Department of Economy of Natural Resources, University of National and World Economy, Sofia, \\ Bulgaria
}

\begin{abstract}
The rural development program plays a key role in their sustainable and effective rural and agricultural development. The purpose of the report is to present the main changes, objectives, priorities, tasks of the rural development program in the second programming period - 2014-2020, and on this basis, to assess their role for the sustainable and multifunctional development of these areas.
\end{abstract}

Key words: rural development program, sustainable development, multifunctional agriculture

\section{INTRODUCTION}

European rural areas are diverse in terms of geographical and climatic features, rates of development, sectors and sustainability. They are characterized by lower levels of income and employment and higher levels of unemployment, unfavorable demographic situation, slower skill development and human capital, and lack of opportunities for women and young people to develop compared to urban areas. Rural development policy seeks to create a coherent and sustainable framework to support the future development of these rural areas. It is also closely linked to other policies set at European Union level, to the EU's Lisbon Strategy for Growth and Jobs, to the concept of Sustainable development. Agriculture and forestry are vital for the sustainable use of natural resources in these areas and help to diversify the economy in rural communities. Therefore, rural development policy is a priority of the EU.

The purpose of the report is to present the main changes, objectives, priorities, tasks of the rural development program in the second programming period - 2014-2020, and on this basis, to assess their role for the sustainable

\footnotetext{
*Correspondence to: Albena Miteva, Sofia, UNWE, Economy of Natural Resources Department, tel: 0888 869620, e-mail: albenakm@yahoo.com
}

and multifunctional development of these areas.

\section{CHARACTERISTICS OF THE EUROPEAN RURAL DEVELOPMENT POLICY}

The Common Agricultural Policy (CAP) aims to achieve stability in the supply of quality food to EU consumers, increase labor productivity in agriculture, to achieve stable prices and guarantee a decent life and acceptable standard of living for farmers, as well as conservation of the European heritage in rural areas and the environment. Its implementation requires a strong focus on rural development. The first attempts for $\mathrm{EU}$ intervention in regional development can be found in the Treaty of Rome (1957) (10). 30 years later, the intention to pursue regional policy was clearly expressed in Article 130a of the Single European Act (1987): "In order to promote its overall harmonious development, the Community is developing and implementing its own initiatives which strengthen its economic and social convergence. In particular, the Community shall aim at reducing the disparities between the levels of development of the various regions and the backwardness of the least favored regions."

The successive enlargements of the European Union and the inclusion of relatively poorer 
MITEVA A., et al.

member states such as Greece, Spain and Portugal in the $1980 \mathrm{~s}$ contributed to the development of rural development policy with a view of reducing regional disparities. In the Maastricht Treaty (1992), the words "including rural areas" were added at the end of Article 130a. With this treaty, the concept of economic and social cohesion becomes one of the three pillars of the EU, together with the single market and the economic and monetary union.

Socio-economic disparities between regions are the main reason for implementation of rural development policy to improve the socioeconomic situation in rural areas and to reduce the socio-economic disparities between urban and rural areas on the one hand and within the framework of the rural regions on the other hand. Regional policy includes all forms of state intervention designed to improve the geographical distribution of economic activities. It aims at achieving several interrelated goals: economic growth and improving the quality of life and preserving the natural and cultural heritage of the region. In this way, regional policy is trying to remove the spatial effects of a free market economy (10). Regional policy includes a wide range of measures aimed at diversifying the economy, improving transport and communication networks, managing human resources, access to basic services, providing business facilities, and more. The reduction of regional disparities is not only an important issue at national level but also at EU level.

With the development of the CAP, especially since the adoption of Agenda 2000, the understanding of the European agricultural model, which aims not only to ensure sustainable and diverse food production, but also the efficient use of agricultural potential by promoting multifunctional development of agriculture, which exceeds the classical productive function of agriculture. Promoting a multifunctional European agricultural model $(1,7,12)$ includes an integrated approach to the agricultural sector, achieving the economic and social viability of European farms by applying a fair farm price mechanism to farmers who reduce their dependence on financial support measures of the CAP and promote an increase in the employment rate in the agricultural sector and stimulate the creation of sustainable jobs. According to some authors $(1,5,6)$, the impact of the CAP on the European agricultural sector on production and consumption has triggered the restructuring of production structures and the strengthening of the role of rural development policy.

\section{PRIORITIES OF THE PROGRAM FOR RURAL DEVELOPMENT FOR THE PERIOD 2014-2020}

In the 2014-2020 period, the CAP focuses on enhancing the competitiveness of the agricultural sector in economic and environmental terms, fostering innovation, combating climate change and supporting employment and growth in rural areas. The aim of these changes is to make green the farm payments by introducing environmentally sound farming practices and a fairer distribution of aid in order to reduce large disparities in income support levels for farmers across the EU and to reduce payments above certain size for the largest agricultural holdings. The focus is also on more targeted income support for the most deprived farmers, especially young farmers, farmers in low-wage sectors and in areas with natural constraints. The reform of the CAP covers not only the measures aimed at strengthening the European agricultural model but also the transformation of the agricultural sector itself $(1-4,8)$ by increasing its competitiveness and the ability to generate high levels of added value, at the same time account is also taken of the potential to promote other activities (9). Putting as one of the objectives of CAP achieving a high degree of economic efficiency, involves increasing the links between the effective use of available resources (land, water, labor) on the one hand and the need to protect the environment on the other.

Ensuring the vitality and competitiveness of European farms is a key element in assessing the potential of European agriculture against the backdrop of the volatility of farm prices in rural areas in some European countries. Harmonizing the competitive conditions for European farmers, achieved through reconfiguration of the direct payments system, needs to improve the conditions for agricultural production by supporting the transition to diversification and multifunctionality in rural areas.

In order to achieve these objectives, the structure of the individual pillars of the CAP is preserved. The first pillar includes income support measures and market management measures, and the second pillar encompasses rural development measures.

Income support is mainly provided through the direct payments scheme. Six CAP schemes 
have been set up to pay the direct payments for 2014-2020. The aim is to organize these schemes more focused, fairer and more environmentally friendly. In the case of direct payments, a gradual reallocation of support to Member States or regions is being made to reduce the greatest differences in the levels of support received by EU farmers.

For the first time, decoupled aid turns into a multifunctional support system. The phase of decoupling from agricultural aid in favor of a common income support launched in 2003 is replaced by a phase of reunification of the instruments around specific objectives, removing any historical reference. Single payment for farms is replaced by a system of payments at levels comprising seven components: 1) "basic payment"; 2) greening payment in favor of environmental public goods ("greening" component); 3) additional payment for young farmers; (4) a redistribution payment enabling the aid to be increased for the first hectares of a holding; 5) additional income support in areas with specific natural constraints; (6) coupled aid; 7) lastly, a simplified scheme for small farmers. Member States allocate around $70 \%$ of their national direct payment portfolio under the new Single
MITEVA A., et al. Payment Scheme (SPS), after deducting all the amounts earmarked for young farmers and other voluntary payments. Compulsory measures are the "basic payment", greening payment in favor of environmental public goods, additional payment for young farmers, each country deciding on its own which of the other measures to apply.

With regard to direct payments, it is important to note that mandatory conditions for greening of agriculture are laid down, the noncompliance of which leads to significant sanctions. As a positive point, it can be appreciated that this aid per hectare is intended only for active farmers.

The European Economic and Social Committee defines that achieving a sustainable level of farmers incomes, improving the functioning of supply chains for agricultural products and foodstuffs, restoring farmers' market power and fair distribution of income among agri-food channels are fundamental in order to ensure the continuation of agricultural activity in many rural areas of Europe. (13)

Table 1 shows the EU-28 direct payment schemes in 2014-2020.

Table 1. Direct Payments Schemes for the CAP 2014-2020

\begin{tabular}{|c|c|c|}
\hline $\begin{array}{l}\text { Mandatory schemes (all Member } \\
\text { States / }\end{array}$ & $\begin{array}{l}\text { Voluntary Schemes (Optional by } \\
\text { Member States) }\end{array}$ & $\begin{array}{l}\text { Simplified scheme for } \\
\text { small farmers }\end{array}$ \\
\hline Basic payment (or area payment) & Redistribution payment & \multirow{5}{*}{ 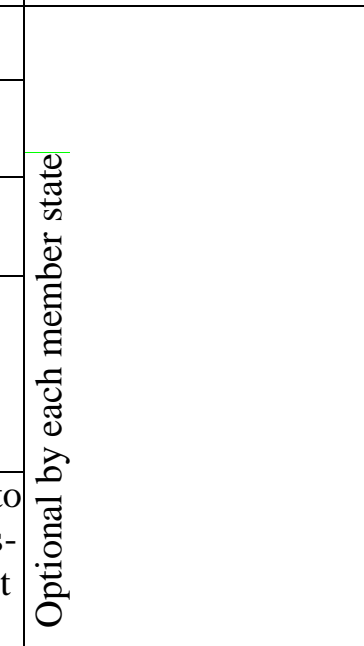 } \\
\hline Greening payment & $\begin{array}{l}\text { Income support in areas with } \\
\text { specific natural constraints }\end{array}$ & \\
\hline $\begin{array}{l}\text { Payment scheme for young } \\
\text { farmers }\end{array}$ & Coupled aid & \\
\hline \multicolumn{2}{|c|}{$\begin{array}{l}\text { Cross-compliance consists of the following two mandatory rules: } \\
\text { statutory requirements for management and good environmental } \\
\text { practices. Farmers must comply with these rules, otherwise they risk } \\
\text { losing fully and partially received direct payments. }\end{array}$} & \\
\hline \multicolumn{2}{|c|}{$\begin{array}{l}\text { Access to the Farm Advisory System - set up by each Member State to } \\
\text { advise farmers on binding themes such as: greening production, cross- } \\
\text { compliance, sustainable use of pesticides and some rural development } \\
\text { measures. }\end{array}$} & \\
\hline
\end{tabular}

Source /13/

The Common Market Organization (CMO) includes the market measures foreseen under the Common Agricultural Policy (CAP). There is a gradual increase in the further orientation of this policy towards the markets and the reduction of the scope of the intervention instruments. These intervention tools are considered as "safety net", which should only be used in the event of a crisis. Member States can use the risk prevention mechanism of rural development programs by setting up a mutual fund to support the stabilization of farm incomes if they are reduced by more than $30 \%$, can create a crisis emergency reserve. 
CAP for the period $2014-2020$ r. retains the two pillars but increases the links between them, thus providing a more holistic and integrated approach to support and achieve the goals. The consolidation of the two pillars of the CAP is strengthening: the first pillar, which finances direct aids and market measures, is entirely at the expense of the EAGF; the second pillar which supports rural development is co-financed. The modulation of direct aids in favor of the second pillar is abolished and is replaced by a mandatory reduction in basic payments of over EUR 150 000. Flexibility between pillars is also increased. From 2015. Member States have the possibility to initially transfer funds in both directions (up to $15 \%$ from the first pillar to the second, and up to $25 \%$ from the second pillar in some countries).

The 2014-2020 rural development policy has clearly formulated objectives that are compatible with those of the CAP as a whole competitive food production, sustainable management of natural resources and adaptation to climate change and ensuring balanced territorial development. These objectives are also in line with the Europe 2020 strategy, focusing on employment, growth, innovation, education, social inclusion and climate / energy. It has been restructured to increase its efficiency. A more integrated, targeted and territorial approach to rural development is applied. Better coordination of rural measures with other EU structural and investment funds is envisaged.

Are strengthened the links with EU structural and investment funds, which will allow EU funds from different sources co-financed by Member States to support a wider range of innovative projects. To achieve the objectives of the Europe 2020 strategy is envisaged a closer cooperation and coherence with other European structural and investment policies for rural areas. While EU rural development policy is supported by the EAFRD, four other EU funds can also provide support: the European Regional Development Fund, the European Social Fund, the Cohesion Fund and the European Maritime and Fisheries Fund, known as the European Structural Funds and investment funds. Each Member State concludes a partnership contract with the European Commission on the basis of a national strategic plan outlining the investment priorities for the five Funds. In the financial period 2014-2020, these funds are managed by a common set of general rules that provides for more effective use of the different sources of funding.

Member States continue to develop their own rural development programs in response to their needs, which are endorsed by the EU. The priorities for rural development on which the CAP 2014-2020 focus are summarized in six areas. They are knowledge transfer and innovation support; raising the competitiveness of farms at a higher level; better organization of the food chain, animal welfare and risk minimization; minimize harmful environmental impacts; making full use of resources and supporting the green economy in the field of agriculture; increasing employment and reducing poverty in rural areas. These rural development programs cover at least four of the six priorities and set quantitative targets for them. Indicate which measures (from the list provided by the EAFRD Regulation) will be used to achieve the objectives and the allocation of funds under measures. It is worth noting that "innovation", "environment" and "mitigation and adaptation to climate change" are cross-sectoral objectives common to all European structural and investment funds that must be the subject of all rural development measures.

The EAFRD during this programming period allows Member States to offer specific support to specific groups, regions and targets, including specific sub-programs within their RDP. They may concern young farmers, mountain areas, women in rural areas, small farms, short supply chains, mitigation and adaptation to climate change and biodiversity conservation. The large set of existing instruments under the second pillar of the CAP is being reduced and their management simplified focusing on supporting competitiveness, innovation, knowledge-based agriculture, the entry of young farmers, the sustainable management of natural resources, and balanced territorial development.

These measures are mainly determined by the type of beneficiary (young farmers, state and private forest owners, SMEs) and the type of support (payments per hectare, investment support, etc.). New measures have been introduced to meet emerging needs: a risk management tool, cooperation and start-up tools for LEADER. There is an increased flexibility in the choice of measures, and they can be used in combination and each of them can serve one or more priority areas. 
As with the first pillar of the CAP, mandatory eco-targets exist. Are enhanced the environmental and climate measures. Their implementation is still mandatory, with at least $30 \%$ of the total rural development budget allocated to environmental measures, adaptation to climate change and mitigation, including in the agricultural and forestry. It is excluded the double funding for greening under both pillars, thus ensuring that farmers are not paid twice for the same activity.

The CAP budget for 2014-2020 accounts for about $38 \%$ of the total EU budget. The total cost of the CAP is EUR 408.31 billion. The distribution between the two pillars of the CAP is for pillar 1: $76.6 \%$ of the CAP budget, corresponding to $29 \%$ of the EU budget, or 312.74 billion euro, and for pillar 2: $23.4 \%$ of the CAP budget, which corresponds to $9 \%$ of the EU budget, or 95.58 billion euros.

The policy is fully in line with the objectives of the Europe 2020 strategy for smart, sustainable and inclusive growth. A specific feature of the policy is that national, regional and local authorities are responsible for the development and implementation of their seven-year rural development programs based on EU priorities and a "menu" of measures proposed in the European Agricultural Fund for Rural Development, which provides cofinancing from the EU. The increased flexibility of the new policy means that it offers support that is more in line with the specific needs of each region or country.

\section{CONCLUSION}

It can be summarized that there is a reorientation of policies from intensive support for Pillar I / direct payments and CMO activities/ to strengthening rural development measures and multifunctional agriculture in Pillar II. Promoting rural development measures brings greater benefits to old EU members who have been able to develop competitive agricultural production. Some measures to promote business development or the provision of financial aid to build producer groups can strengthen and build competitive agricultural production in the new EU Member States as well. Achieving the new requirements needs intensified integration along the food supply chain to increase the supply of European agricultural products and promote an environmentally responsible farming.

The development of the CAP reveals the complex configuration and mutual influence between agricultural production, the development of other sectors and industries in rural areas, the rural area itself, its landscape, underground and terrestrial resources, the rural communities themselves and the European economy as a whole. The CAP, through its complexity and implementation mechanism, satisfies numerous political and economic challenges and has a key role for the development of European rural communities, at least in terms of agricultural production and securing the European food safety as well as environmental protection. Emphasizing the role of the European multifunctional model of rural development and its transformation under the impact of CAP reforms allows the agricultural potential to be assessed and to promote its values.

\section{REFERENCES}

1. Andrei J.V., Gheorghe P.(2014).Economy in Romania and the Need for Optimization of Agricultural Production Structures, Peter Lang $\mathrm{GmbH}$, Frankfurt am Main, Germany.

2. Badea L, Mieila, M.(2008). The economic efficiency of field crops cultivation in south Romania: trends and actions for improvement, Annales Universitatis Apulensis Series Oeconomica, 1(10):328:326.

3. Bougherara, D., Latruffe, L., (2010) Potential impact of the EU 2003 CAP reform on land idling decisions of French landowners: results from a survey of intentions. Land Use Policy 27, 1153-1159.

4. Brady, M., Kellermann, K., Sahrbacher, C., Jelinek, L., (2009). Impacts of decoupled agricultural support on farm structure, biodiversity and landscape mosaic: some EU results. J. Agric. Econ. 60, 563-585

5. Chambon, N., Fernandes, S. (2010), How to Reform CAP to improve agriculture's contribution to the Europe 2020 Strategy?, Notre Europe.

6. Ciutacu, C., Chivu L., Andrei, J.,V.(2015).Similarities and dissimilarities between the EU agricultural and rural development model and Romanian agriculture. Challenges and perspectives, Land Use Policy, (46):258-266

7. Ene, C (2013), Food Traceability-Actual Coordinates at National, European and International Level, Quality - Access to Success, 14(135):103-107.

8. Hart, K., Baldock, D., Weingarten, P., Osterburg,B., Povellato, A., Vanni, F., Pirzio-Biroli,C., Boyes, A.(2011). What Tools for the European Agricultural Policy 
MITEVA A., et al.

to Encourage the Provision of Public Goods, European Parliament, Directorate General for Internal Policies Policy Department B: Structural And Cohesion Policies, Brussels, June 2011, available at: http://www.ieep.eu/assets/835/PG FINAL.pdf

9. Ungureanu, A. 2015, The importance of Romanian mountain tourism for the national economy, Economics of Agriculture, 62, (3):849-868

10.Vanhove, N. (1999), Regional policy: A European approach. Aldershot: Ashgate, third edition.

11. Vasile A., Panait M., Alecu A., Transformations of Eurpean Agricultural sector, market and model under the influence of Common Agricultural Policy, PRRA Paper N 69556, /2015/

12.Zaman, G. 2012. Challenges and requirements for sustainable development of Romania's agriculture based on the input-output analysis, Romanian Journal of Economics, (2):5-15

13.European Commission.2015.EU-28 Direct payments schemes overview in 2015, Agriculture and Rural Development, available at:http ://ec.europa. eu/agriculture/direct-support/directpayments/docs/direct-payments-schemes en.pdf 